\title{
Neurotensin-secreting carcinoma of the bronchus
}

\author{
J. R. WOOD \\ B.Sc., M.B., B.S. \\ Y. C. LEE \\ B.Sc.
}

\author{
S. M. WooD \\ B.Sc., M.B., B.S. \\ S. R. BLOOM \\ M.A., D.Sc., M.D., F.R.C.P.
}

Department of Medicine, Royal Postgraduate Medical School, London W12 OHS

\begin{abstract}
Summary
Neurotensin, a neuroendocrine peptide present in gut and brain has previously been found in pancreatic tumours secreting several other peptides. We report here the first case of a patient with a neurotensinsecreting adenocarcinoma of the bronchus.
\end{abstract}

KEY WORDS: neurotensin, bronchus, adenocarcinoma.

\section{Introduction}

In recent years a number of new regulatory peptides have been isolated from the gastrointestinal tract and central nervous system. Neurotensin, originally found in bovine hypothalamus and subsequently isolated from the human gastrointestinal tract, is a new member of this peptide group which has a wide range of potent biological actions. In man these include inhibition of gastric acid secretion, relaxation of the lower oesophageal sphincter and vasoconstriction in adipose tissue (Hamer and Leeman, 1981). Neurotensin-like material has recently been isolated from pancreatic tumours secreting vasoactive intestinal polypeptide and other regulatory peptides (Gutniak et al., 1980; Feurle et al., 1980; Blackburn et al., 1981). We report here the presence of neurotensin-like immunoreactivity in tumour and plasma of a patient with an adenocarcinoma of the bronchus.

\section{Case report}

A 68-year-old retired engineer presented with a six week history of pain in both knees, unrelated to movement and relieved by analgesics. He had a dry cough without other respiratory symptoms and had recently lost half a stone in weight. Past medical history included a partial gastrectomy for duodenal ulcer and a right axillary basal cell carcinoma. There was no history of diabetes mellitus. He smoked 15 cigarettes a day and had had occupational exposure to asbestos between 1971 and 1976 .

Examination was normal except for finger clubi ing and tenderness over the lower third of his le? tibia. Routine haematology, urea, electrolytes and liver function tests were normal. A fasting bloof glucose was $13.4 \mathrm{mmol} /$ litre. Chest X-ray showed a irregular opacity in the posterior and lateral segment of the right lower lobe and an enlarged hilum chest X-ray 6 years previously had been nor fase Changes of hypertrophic pulmonary osteorartir pathy were seen on radiographs of the left tibis technetium bone scan showed no evidence of mets stases. A diagnosis of bronchial carcinoma was mad on percutaneous needle biopsy and a right pneumos nectomy performed. Histological examination of the resected lung revealed two discreate areas of mucin secreting adenocarcinoma in the right upper ang lower lobes with involvement of hilar and oesophas geal lymph nodes.

\section{Results}

Extracts from the patient's tumour contained 8. $\mathrm{pmol} / \mathrm{g}$ wet weight of neurotensin-like immunoreaes tivity measured by radioimmunoassay using a spe ${ }^{3}$ cific rabbit antiserum and $I^{125}$ labelled synthetis neurotensin (Blackburn and Bloom, 1979). Gel pers meation chromatography showed the presence of tw molecular forms of neurotensin-like immunoreago tivity one of which coeluted with the synthetic tro decapeptide (Fig. 1). Neurotensin was undetectabld in macroscopically normal lung tissue taken distarte from the tumour site. Somatostatin, bombesin, vasoo active intestinal polypeptide (VIP), gastrin, substance $P$ and cholecystokinin were all undetectable i tumour extracts.

Fasting plasma contained $200 \mathrm{pmol} /$ litre of neuroto tensin-like immunoreactivity (normal $<10 \mathrm{pmol} \Phi$ litre) which fell to $37 \mathrm{pmol} /$ litre postoperatively 


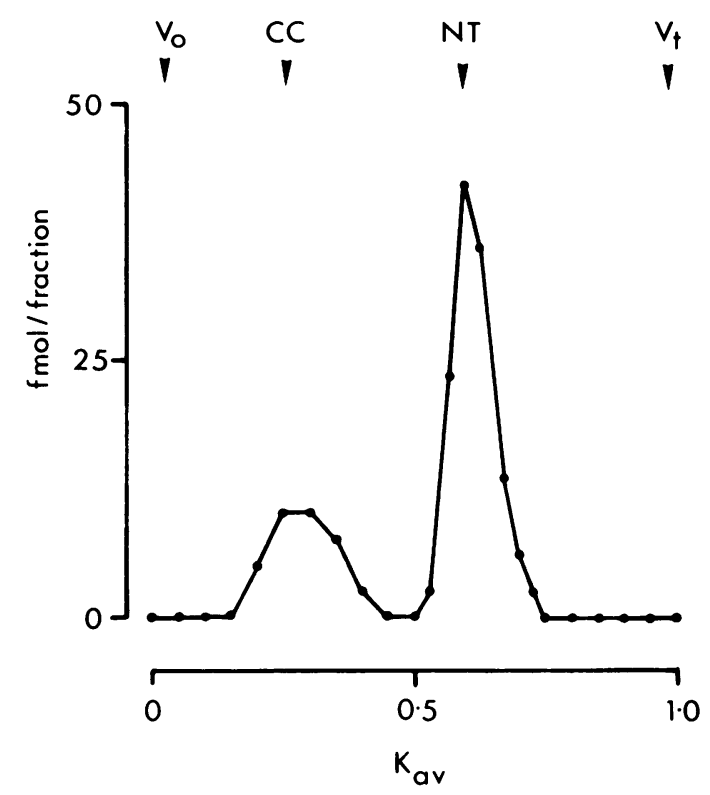

FIG. 1. Gel permeation chromatography profile of the extract of the patient's tumour run on a Sephadex G50-superfine gel column calibrated with dextran blue (Vo), cytochrome C, 12'I-labelled neurotensin and $\mathrm{Na}^{12} \mathrm{I}(\mathrm{Vt})$ as molecular size markers.

Somatostatin, bombesin, gastrin, cholecystokinin, substance P, VIP, calcitonin, thyroid stimulating hormone, adrenocorticotrophic hormone, follicle stimulating hormone and luteinising hormone were all undetectable in plasma.

\section{Discussion}

This is the first description of neurotensin-like material in a lung tumour. Neurotensin-like immunoreactivity has recently been found in pancreatic tumours in association with abnormal production of other peptides. Six out of twenty-one tumours producing VIP also contained neurotensin-like immunoreactivity (Blackburn et al., 1981), two of which were associated with high plasma neurotensin concentra- tions. Neurotensin-like immunoreactivity has also been found in two other mixed endocrine tumours, one patient presenting with the Zollinger-Ellison syndrome (Feurle et al., 1980), the other with watery diarrhoea (Gutniak et al., 1980).

In contrast to pancreatic tumours only neurotensin (within the limitation of the peptides measured) was detected in the present tumour. This case therefore provided an opportunity to assess the clinical effects of neurotensin hypersecretion. The contribution of an elevated plasma neurotensin to the clinical course of the present patient, however, remains speculative. Fasting hyperglycaemia in a cachectic, anorexic man is unusual and may be relevant as neurotensin induces hyperglycaemia in animals. The patient reported by Gutniak and colleagues was also diabetic but this may have related to the elevated VIP concentration. Neurotensin has vascular effects in animals and might therefore have contributed to the clubbing and hypertrophic pulmonary osteoarthropathy.

\section{Acknowledgment}

We are grateful to Mr J. R. Belcher for permission to report details of his patient.

\section{References}

Blackburn, A.M. \& Bloom, S.R. (1979) A radioimmunoassay for neurotensin in human plasma. Journal of Endocrinolog.: 83, 175. Blackburn, A.M.. Bryant. M.G.. Adrian. T.E. \& Bloom. S.R. (1981) Pancreatic tumours produce neurotensin. Journal of Clinical Endocrinology and Metabolism, 52, 820.

FeUrle. G.E.. Helmstaedfer. V. Tischbirek. K.. Carraway. R.. Grube, P. \& ForsSmanN, W.G. (1980) A new endocrine tumour entity -a multihormonal neurotensinoma. Reg Pep. (Suppl. 1). 35.

GUtNiak. M., RosenqVist, U., Grimelius. L.. LUNDberG. J.M.. Hokfelt, T., Rokaeus, A.. Rosell. S., Lundquist, G.. Fahrenkrug, J., Sundblad, R. \& Gutniak, E. (1980) Report on patient with watery diarrhoea syndrome caused by a pancreatic tumour contacting neurotensin, enkephalin and calcitonin. Acta Medica Scandinavica, 208, 95.

HAMER. R.A. \& LEEMAN. S.E. (1981) Neurotensin and actions. In: Gut Hormones (Ed by Bloom S.R. \& Polak. J.M.) p. 42, 290. Churchill Livingstone, Edinburgh.

(Accepted 6 May 1982) 